\title{
E-Policy: Designing E-Aparatur in Bandung City
}

\author{
Yogi Suprayogi Sugandi \\ Department of Public Administration \\ Universitas Padjadjaran \\ Bandung, Indonesia \\ yogi.suprayogi@unpad.ac.id \\ Dedi Sukarno \\ Department of Public Administration \\ Universitas Padjadjaran \\ Bandung, Indonesia \\ dedisukarno@gmail.com
}

\author{
Sawitri Budi Utami \\ Department of Public Administration \\ Universitas Padjadjaran \\ Bandung, Indonesia \\ sawitribudiutami@gmail.com \\ Ramadhan Pancasilawan \\ Department of Public Administration \\ Universitas Padjadjaran \\ Bandung, Indonesia \\ ramadhanpancasilawan@gmail.com
}

\begin{abstract}
The aim of this paper is to describe three policies issued, they are: analysis of civil servant job; electronic-based policy named electronic aparatur (e-Aparatur), and harmonization of the evaluation of job information policy for civil servants. This research used policy gap method to find similarity and difference between one policy and other policies. There are 15 policies used in making the process business, 7 main policies and 8 supporting policies in this application. The transformation of business processes from the rules into one way of mapping various policies. The purpose of this paper is to describe how to transform policy variations into an electronic policy. An electronically designed policy is to simplify overlapping policies. Electronic policy is indispensable in support of more efficient public services. Policies that regulate human resources should not be too complicated by various rules, electronic policy can simplify it. In the process of compilation is experiencing problems, one of them is the input and output process constraints. This process should primarily involve skilled employees in information technology literacy.
\end{abstract}

Keywords: e-policy; regulation; application;civil service

\section{INTRODUCTION}

In order to support the realization of good governance, Ministry for State Apparatus Empowerment $(P A N)$ has been coordinating the making and running of Bureaucratic Reform Program. The program is aimed to improve effectiveness, efficiency, transparency and accountability of governance. This aim can be accomplished through various activities, such as staffing of Civil Servants. In staffing, it is required to have basic information, namely job information obtained from job analysis. Therefore, the first step to be performed is job analysis. This step is aimed to obtain information on job characteristics in each work unit, and then to be formulated as a position.

Job formulation, then, is made as basis for management activites in personnel field, such as job mapping. From this job map, together with result of workload analysis, employee requirement per position can be made. Thus, job analysis is absolutely required by all government agencies to determine organizational composition and required number of civil servant.

Bandung city government, until today, regards that job analysis is one of urgent process in human resource management in order to optizime the empowerment and utilization of human resource in performing main duties and functions, so that each and every employee, either in structural and non-structural position in the environment of Bandung City Government, shall have clear authority and responsibility as manifested in job description and job specification.

Currently there are three regulations that govern job analysis in Indonesia. Those are Regulation of the Head of National Civil Service Agency No. 12 of 2011, Regulation of Minister of State Apparatus Empowerment and Bureaucratic Reform No. 33 of 2011 and Regulation of Minister of Home Affairs No. 35 of 2012. Therefore, this paper formulates an application called E-Aparatur to facilitate the user in using one application to obtain 3 results. Researchers working in collaboration with Bandung City Government to develop this application. Each of those three policies has a different task, thus the present study merges those policies into an electronic application. It is a webbased application, accessible at the address: http://eaparatur.bandung.go.id. Bandung City Government provides some hardware infrastructures for this application. The frontend of this E-Aparatur application is shown in Figure 1 below.

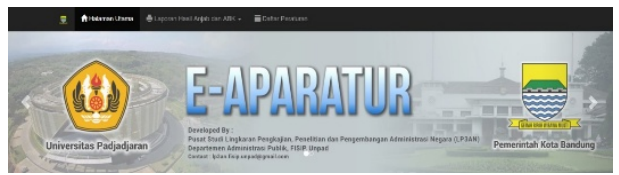

Figure 1. E-Aparatur Application

Source: E-Aparatur Application, 2016

E-Aparatur was developed since the end of 2015 as part of an effort to answer the need of staffing in local government in carrying out job analysis and workload analysis, particularly in Bandung City Government. E-Aparatur is an offline and online

Corresponding authors: Yogi Suprayogi Sugandi 
application installed on a server or cloud that supports the process of filling job analysis and workload analysis in one place and one time, equipped with the ability to print report in accordance with the requirements of job analysis regulation and workload required as seen in Figure 2. For the process of filling the position [1] users only need to click and input data both on the job analysis and the workload analysis menu.

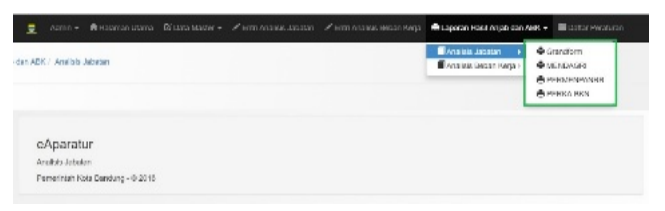

Figure 2. Job and workload analysis menu Source: E-Aparatur Application, 2016

Result of the job analysis and workload analysis input [2] can be downloaded and printed in a PDF format that can be customized according to needed regulation as shown in Figure 3 and Figure 4.

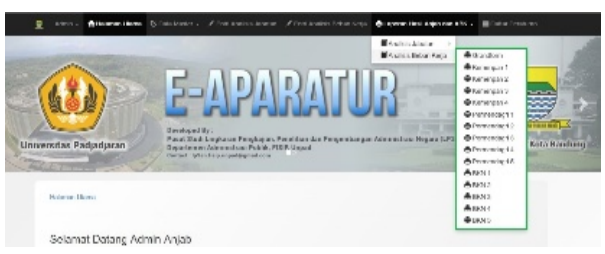

Figure 3. Report Position Analysis

Source: E-Aparatur Application, 2016

To simplify the supervision in the process of filling E-Aparatur application, Figure 1.5 offers a concept of 1 username for 1 SKPD and master data modification [6] controlled by 1 admin. This is carried out so that the filling process can be objective without any interference related to the filling up to printing of final report [8].
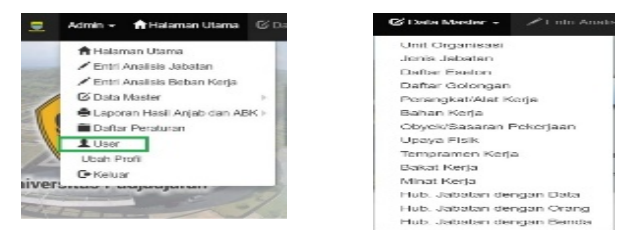

Figure 4 Work Load Analysis Report

Source: E-Aparatur Application, 2016

\section{RESEARCH METHOD}

This e-Apparatus answers the deadlock to be done by central and local governments, especially to prepare Job Analysis, consisting of Job Information, Job Name, Job Resume, Job Description and Job Map [3] , that exists in each organizational unit in both the central and regional levels. The method used is (A) analyzing three rules governing the job analysis to be (B) transformed into a policy that is directly accessible by users of the policy who are the civil servants both at the central government and regional levels. The disharmony of these three regulations is caused by the policy of each government agency overlap the budgeting and the same tasks in each organization.
The policy on Job Analysis of the Ministry of Home Affairs in the form of Minister Regulation No. 35 of 2012 on Job Analysis in the Ministry of the Domestic Affairs and Local Government, Ministry of Administrative Reform and Regulation of the Minister of Administrative Reform No. 33 of 2011 on Guidelines for Job Analysis and the last regulation issued by the National Civil Service Agency and the Regulation of the Head of National Civil Service Agency No. 12 of 2011 on Guidelines for Job Analysis. Transformation performed on these policies into an application based on information systems and technology can be seen at this link http://eaparatur.bandung.go.id. The link is the beginning of electronic policy [4] in Bandung Government. These three regulations are then combined and analyzed in their common aim and purpose and are transformed into the electronic policy (e-Apparatus). E-Apparatus program is an innovation under the background of the lack of harmony of Indonesian government in formulation of various policies [6]. This paper will also display descriptive method of analysis. After the analysis, these three regulations are then transformed into a simpler electronic policy, without reducing their content and intention. The simple analysis is converted into applications that are easier to input by civil servants in the city government or in the language of the OECD (Organization of Economic Development) named as the application of Government to Employee ( $G$ to E). Each policy [9] has differences in translating the contents of the job analysis, but has the same intention. There are several differences between one policy with other policies [4], but it does not detract from the purpose of identifying the job in question.

\section{RESULTS AND DISCUSSION}

From result of using of the application, there are two types of user. The first one is Administrative Type. This type designs job code specifically for this application. This job code is designed according to the mandatory authority and optional authority to be implemented on regional, the next code is based on type of the Local Agency Organization and ended with the structural position. Administrative type is the type that specifically build organizational structure based on job code. Operator type is the type that generally input various data related to job analysis and workload analysis.

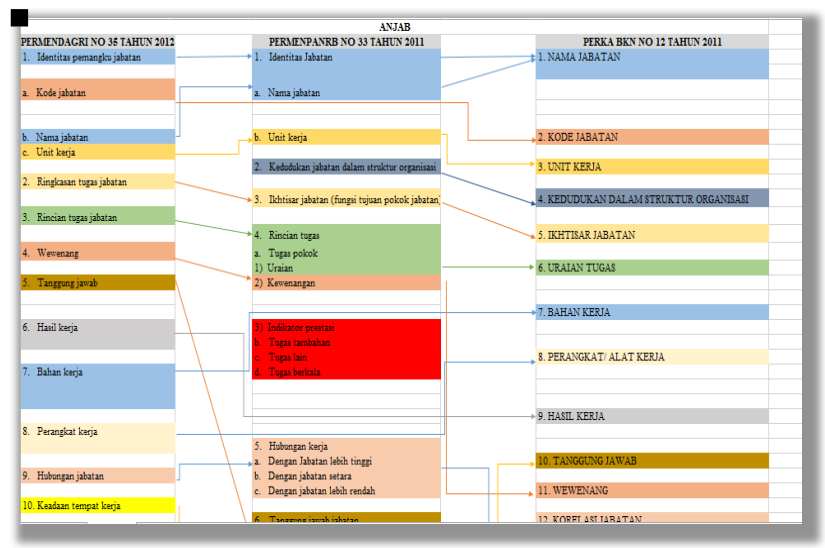

Figure 5. Business Process of Job Analysis of Three Regulations Source: Material of Gap Analysis, 2016 
In designing for entry to a system, researchers design business process based on various regulations, find the similarities of one form to other forms to be then given same name and made into one key unit in the application, such as policy gap analysis [6] as seen in Figure 5 above.

Job analysis procedure can be elaborated as follows:

a. Determining the purpose of job analysis

It is the initial step to be done to determine the purpose of job analysis and what information needed.

b. Planning the job analysis, namely planning that includes:

1. Determining the general information on the organization, such as vision, mission, structure including existing job data, organizational work mechanism, list of employees, data on work environment, and various personnel policies.

2. Determining the components of job information related to job identification, job administration, and job requirement.

3. Determining data collection method, including approach used, sources of data and data collection techniques. The approach that can be used are such as approach based on individual of job holder, sampling, names of equal or same position, and same group of position. Sources of data can be obtained through the individual concerned, the chairman, literature, or other people who know about particular position. Data collection can be performed by methods such as interview, panel of experts, questionnaire, diary/log book, and observation

c. Collecting the job data, carried out within this order:

a) Choosing work unit by which data will be taken.

b) Making inventory of available job within the work unit

c) Making inventory of number of job holder.

d) Determining number of sample in the work unit.

e) Choosing the name of job holder as sample.

f) Collecting data using particular method.

g) Recording in job analysis worksheet.

d. Processing the job data into job information.

e. Presenting the result of job analysis in form of job description, job specification, job classification, job design, and job value.

f. Setting up programs of human resource management.

Several principles that should be carried out in job analysis are:

a. Limitations in a job should be clearly defined regarding the authority and time limit to avoid overlapping with other positions.

b. Job analysis should be based on facts with factual and reliable data to reduce subjectivity.

c. Activity process in a job should be arranged chronologically to evaluate.

d. Situation and condition of a job should be considered so that the analysis can understand the reason why certain job should be done in certain position.

Job analysis procedure can be elaborated as follows:

a. Determining the purpose of job analysis it is the initial step to be done to determine the purpose of job analysis and what information needed.

b. Planning the job analysis, namely planning that includes:

a) Determining the general information on the organization, such as vision, mission, structure including existing job data, organizational work mechanism, list of employees, data on work environment, and various personnel policies.

b) Determining the components of job information related to job identification, job administration, and job requirement.

c) Determining data collection method, including approach used, sources of data and data collection techniques. The approach that can be used are such as approach based on individual of job holder, sampling, names of equal or same position, and same group of position. Sources of data can be obtained through the individual concerned, the chairman, literature, or other people who know about particular position. Data collection can be performed by methods such as interview, panel of experts, questionnaire, diary/log book, and observation

c. Collecting the job data, carried out within this order:

a) Choosing work unit by which data will be taken.

b) Making inventory of available job within the work unit

c) Making inventory of number of job holder.

d) Determining number of sample in the work unit.

e) Choosing the name of job holder as sample.

f) Collecting data using particular method.

g) Recording in job analysis worksheet.

d. Processing the job data into job information.

e. Presenting the result of job analysis in form of job description, job specification, job classification, job design, and job value.

f. Setting up programs of human resource management.

\subsection{Form of Presentation for Result of Job Analysis}

Several forms of presentation for result of job analysis are as follows: a. job description, which is brief explanation written carefully on duties, obligation, responsibility, and authority, of certain job, including:

a) Job identification, comprising of name of job, name of equal job, and code of job,

b) Job characteristics, comprising of description of duty, authority and responsibility, relationship with other job, supervision required, equipment/machine used, work condition, and specific terms to know.

c) Qualification of job holder, comprising of general and specific qualifications.

b. job specification, which is statement on minimum quality of an employee to hold particular position, including:

a) General requirement, comprising of level of education, job experience, and work skills, and work 
knowledge.

b) Specific requirement, comprising of physical condition, sex, talent, interest, emotional state, etc.

c. Job classification, which is classification of positions based on: a) duty classification based on duty and responsibility. b) rank classification, based on ranking of position.

d. Job design, which is a design of activities in certain job. After job analysis and organizational structuring, job design can be carried out in simple, global way and in specific, detailed way. For organization with old structure, restructuring or job redesign can be performed, so it can have job enlargement, job enrichment, and job value. Job enlargement is expansion of a job by expanding the duties in the job horizontally in order to anticipate work dissatisfaction of employee toward their job through expansion their work scope. For example, an employee who was only charged to make report can have new duty of analyzing the report. Job enrichment is expansion of a job by expanding the duties in the job vertically through addition of authority and responsibility vertically. Job value is value of a job, obtained by comparing job content to job specification of a job to other. This comparation is called job evaluation. Job value defines the amount of compensation.

Information for job analysis can be collected by these methods: interview, panel of experts' questionnaire, diary/logbook, observation.

Result of job analysis is presented in forms of: job description, job specification, job classification, job design. Table 1 explains the advantages and disadvantages of EAparatur application development that should be improved so that the purpose of staffing can be achieved [10].

Table 1 Advantages and Disadvantages of E-Aparatur Application after input test in 2016

\begin{tabular}{|c|c|}
\hline Advantages & Disadvantages \\
\hline $\begin{array}{l}\text { 1. E-Aparatur has facilitated } \\
\text { the process of filling job } \\
\text { and workload analysis in } \\
\text { one application. }\end{array}$ & $\begin{array}{l}\text { 1. Result of job mapping still } \\
\text { needs development to be } \\
\text { integrated with the job } \\
\text { code and the value of the } \\
\text { accumulated assessment of } \\
\text { workload. }\end{array}$ \\
\hline $\begin{array}{l}\text { 2. E-Aparatur can be } \\
\text { installed offline and online } \\
\text { in server and cloud. This } \\
\text { way, users can use the } \\
\text { application anytime and } \\
\text { anywhere using supported } \\
\text { devices. }\end{array}$ & $\begin{array}{l}\text { 2. Feature for printing report } \\
\text { for each SKPD is not yet } \\
\text { available. }\end{array}$ \\
\hline $\begin{array}{l}\text { 3. E-Aparatur uses user } \\
\text { friendly features and } \\
\text { menus in order to obtain } \\
\text { expected results in } \\
\text { accordance with the } \\
\text { expected target and time. }\end{array}$ & $\begin{array}{l}\text { 3. Features for filling } \\
\text { workload analysis is not } \\
\text { yet efficient because users } \\
\text { still have to click each job } \\
\text { description in different } \\
\text { pages. }\end{array}$ \\
\hline $\begin{array}{l}\text { 4. Job and workload analysis } \\
\text { report are expected to be } \\
\text { able to be adjusted to the } \\
\text { necessary regulation by } \\
\text { doing only one process of } \\
\text { filling. }\end{array}$ & $\begin{array}{l}\text { 4. Time standard for the } \\
\text { executing and functional } \\
\text { officers has not been } \\
\text { formulated. }\end{array}$ \\
\hline
\end{tabular}

Table 1. continued

\begin{tabular}{|l|l|}
\hline 5. $\begin{array}{l}\text { The application supports } \\
\text { usernames management } \\
\text { administered by an admin } \\
\text { so that the quality of filling } \\
\text { job and workload analysis } \\
\text { is accountable. }\end{array}$ & $\begin{array}{l}\text { Job code in the job analysis } \\
\text { form still needs } \\
\text { formulation so that the } \\
\text { result of job and workload } \\
\text { analysis can be well- } \\
\text { managed. }\end{array}$ \\
\hline 6. $\begin{array}{l}\text { E-Aparatur master data is } \\
\text { dynamic and can be } \\
\text { managed by the } \\
\text { administrator to facilitate } \\
\text { any user data modification. }\end{array}$ & $\begin{array}{l}\text { This application will later } \\
\text { be adaptive to the needs of } \\
\text { other apparatus data such } \\
\text { as: job evaluation, } \\
\text { remuneration, etc. }\end{array}$ \\
\hline 7. $\begin{array}{l}\text { Guidelines and regulations } \\
\text { that support the filling } \\
\text { process of job and } \\
\text { workload analysis are } \\
\text { provided in a specified } \\
\text { feature so that users focus } \\
\text { more on filling everything } \\
\text { in one application. }\end{array}$ & $\begin{array}{l}\text { This application can be } \\
\text { made available in Android- } \\
\text { based devices. }\end{array}$ \\
\hline 8. & $\begin{array}{l}\text { E-Aparatur provides a } \\
\text { search feature to find } \\
\text { filling process and } \\
\text { reporting features with a } \\
\text { variety of search filters. }\end{array}$ \\
\hline $\begin{array}{l}\text { E-Aparatur supports } \\
\text { multi-user process for up } \\
\text { to hundreds of users in the } \\
\text { process of filling and } \\
\text { printing of job and } \\
\text { workload analysis. }\end{array}$ & $\begin{array}{l}\text { This application has an } \\
\text { automatic signature feature } \\
\text { for all existing report } \\
\text { validation. }\end{array}$ \\
\hline
\end{tabular}

By using E-Aparatur application, following results can be obtained:

1. job descriptions, job requirements, and job mapping can be accessed anytime and anywhere on the go using supported devices;

2. job workload, employee's needs, number of existing employees, retirement estimates, efficiency of units, job performance;

3. E-Aparatur application evolves following the needs of employment data in accordance with applicable regulations.

Job analysis in such system can result in information on job involved such as collecting and recording job information, checking the job information for accuracy, writing job description based on the information, using the information to determine skills, abilities, and knowledge required for the job, updating the information from time to time. Job description in this application could summarize the duties, responsibilities, working conditions, and activities of particular job, and job specification outlines employee qualifications such as education level, job-related experience, knowledge, skill, or abilities that are required to perform a given job.

\section{CONCLUSION}

E-Aparatur application makes the job of inputting job and workload analysis data easier, by cutting the input work and time with a ratio of 1 to 12 . It means that the process of inputting 1 data for three regulations can be completed within 12 times 
faster than before. The use of this application opens a direct and easy access to job description, job requirements, and job mapping. The workload of each job, the employee's needs, the number of existing employees, including the estimates of retirement, unit efficiency and job performance, are also available.

\section{ACKNOWLEDGMENT}

This study is funded by Hibah Internal University of Padjadjaran 2017

\section{REFERENCES}

[1] H.J. Bernardin and R.W. Beatty, R. W. "Performance appraisal: Assessing human behavior at work". Kent Pub. Co. 1984

[2] M.T. Brannick and E.L. Levine, E. L. "Job analysis: Methods, research and applications for human resource management in the new millennium". 2002

[3] M.T. Brannick, E.L. Levine and F.P. Morgeson. "Job and work analysis: Methods, research, and applications for human resource management. Sage. 2007

[4] N. Flynn, Nancy. "The ePolicy handbook. Designing and Implementing Effective E-mail, Internet, and Software Policies". New York, NY: Amacom. 2001

[5] S. Fuentes "Policy Handbook Identification and Evaluation". Policy. 2008

[6] J. Fleming ans E. McLaughlin. "Researching the confidence gap: theory, method, policy" [in special issue: Researching Public Confidence] Policing and Society: An International Journal of Research and Policy, 22, (3), 2012. pp. 261-269.

[7] S. Gael. "The job analysis handbook for business, industry, and government" (Vol. 1). John Wiley \& Sons. 1988

[8] S. Gael, S. Job analysis: A guide to assessing work activities. Jossey-Bass Inc Pub. 1984

[9] R.J. Harvey. Job analysis.

[10] E.J. McCormick. "Job analysis: methods and applications". Amacom. 1979

[11] E. Zimmerman. HR must know when employee surveillance crosses the line. Workforce-Costa Mesa-, 81, 2002, pp. 38 - 45 